\title{
Retraction
}

\section{Retracted: Technique of Intravesical Laparoscopy for Ureteric Reimplantation to Treat VUR}

\author{
Advances in Urology \\ Received 10 January 2016; Accepted 10 January 2016 \\ Copyright (C) 2016 Advances in Urology. This is an open access article distributed under the Creative Commons Attribution License, \\ which permits unrestricted use, distribution, and reproduction in any medium, provided the original work is properly cited.
}

The article titled "Technique of Intravesical Laparoscopy for Ureteric Reimplantation to Treat VUR” [1] has been retracted as it was found to be substantially similar to a previously published article by the same authors. The first article, "Laparoscopy in the management of pediatric vesicoureteral reflux," by Atul A. Thakre, B. Sreedhar, and C. K. Yeung was published in Indian J Urol. 2007 Oct-Dec; 23(4): 414419, while the second article, "Technique of Intravesical Laparoscopy for Ureteric Reimplantation to Treat VUR" was published in Advances in Urology in June 2008.

\section{References}

[1] A. A. Thakre and C. K. Yeung, "Technique of intravesical laparoscopy for ureteric reimplantation to treat VUR," Advances in Urology, vol. 2008, Article ID 937231, 3 pages, 2008. 